\title{
Antimicrobial and allelopathic effects of leaves extracts of Myrcia hatschbachii
}

\author{
Efeitos antimicrobianos e alelopáticos de extratos foliares de Myrcia hatschbachii \\ Efectos antimicrobianos y alelopáticos de los extractos de hojas de Myrcia hatschbachii
}

Received: 06/14/2021 | Reviewed: 06/22/2021 | Accept: 06/26/2021 | Published: 07/12/2021

Larissa Junqueira Gatto

ORCID: https://orcid.org/0000-0001-6451-7445

Federal University of Parana, Brazil

E-mail: lari.gatto@gmail.com

Andressa Veiga

ORCID: https://orcid.org/0000-0001-5470-7317

Federal University of Parana, Brazil

E-mail: dessa.v@gmail.com

Natasha Tiemi Fabri Higaki

ORCID: https://orcid.org/0000-0003-4237-7626

Federal University of Parana, Brazil

E-mail: natasha.fabri@gmail.com

Juliane Nadal Dias Swiech

ORCID: https://orcid.org/0000-0002-5106-9767

Federal University of Parana, Brazil

E-mail: juliswiech@yahoo.com.br

Elisiane de Bona Sartor

ORCID: https://orcid.org/0000-0003-4303-916X

Federal University of Parana, Brazil E-mail: elisartor@gmail.com

Caroline Gribner

ORCID: https://orcid.org/0000-0002-0179-1284

Federal University of Parana, Brazil

E-mail: carol_gribner@yahoo.com.br

Paula Francislaine Moura

ORCID: https://orcid.org/0000-0003-1617-3144

Federal University of Parana, Brazil

E-mail: paulafrancislaine19@gmail.com

Obdulio Gomes Miguel

ORCID: https://orcid.org/0000-0002-2231-9130

Federal University of Parana, Brazil

E-mail: obdulio@ufpr.br

Marilis Dallarmi Miguel

ORCID: https://orcid.org/0000-0002-1126-9211

Federal University of Parana, Brazil

E-mail: marilisdmiguel@gmail.com

\begin{abstract}
Plants have been seen as alternatives for researching natural antimicrobials and herbicides. The aim of this work was to evaluate the antibacterial, antifungal, and allelopathic properties of leaves extracts of Myrcia hatschbachii. The crude extract and fractions were obtained by Soxhlet apparatus. Antimicrobial activity was determined by the minimum inhibitory concentration (MIC) using the broth microdilution method. The ethyl acetate fraction showed activity against Candida albicans (MIC: $62.5 \mu \mathrm{g} / \mathrm{mL}$ ), Staphylococcus aureus (MIC: $500 \mu \mathrm{g} / \mathrm{mL}$ ), and Pseudomonas aeruginosa (MIC: $1000 \mu \mathrm{g} / \mathrm{mL}$ ). Allelopathic activity evaluated the influence of crude extract and fractions on the germination and growth of Lactuca sativa. The crude extract and the chloroform fraction inhibited the growth of the radicle, while the hexane fraction inhibited the growth of the hypocotyl and radicle of lettuce seeds in all concentrations $(100-1000 \mu \mathrm{g} / \mathrm{mL})$. The biological potential of the species motivates further study of new antimicrobial and bioherbicidal agents.
\end{abstract}

Keywords: Allelopathy; Antifungal; Candida albicans; Hypocotyl; Myrtaceae; Radicle.

\section{Resumo}

As plantas têm sido vistas como alternativas para a pesquisa de antimicrobianos e herbicidas naturais. $\mathrm{O}$ objetivo deste trabalho foi avaliar as propriedades antibacteriana, antifúngica e alelopática de extratos foliares de Myrcia hatschbachii. O extrato bruto e frações foram obtidos por Soxhlet. A atividade antimicrobiana foi determinada pela concentração inibitória mínima (CIM) usando o método de microdiluição em caldo. A fração acetato de etila apresentou atividade contra Candida albicans (CIM: 62,5 $\mu \mathrm{g} / \mathrm{mL}$ ), Staphylococcus aureus (CIM: $500 \mu \mathrm{g} / \mathrm{mL}$ ) e 
Pseudomonas aeruginosa (CIM: $1000 \mu \mathrm{g} / \mathrm{mL}$ ). A atividade alelopática avaliou a influência do extrato bruto e das frações na germinação e crescimento de Lactuca sativa. O extrato bruto e a fração clorofórmica inibiram o crescimento da radícula, enquanto que a fração hexânica inibiu o crescimento do hipocótilo e da radícula das sementes de alface em todas as concentrações $(100-1000 \mu \mathrm{g} / \mathrm{mL})$. O potencial biológico da espécie motiva estudos futuros de novos agentes antimicrobianos e bioherbicidas.

Palavras-chave: Alelopatia; Antifúngica; Candida albicans; Hipocótilo; Myrtaceae; Radícula.

\section{Resumen}

Las plantas se han considerado alternativas para la investigación de antimicrobianos y herbicidas naturales. El objetivo de este trabajo fue evaluar las propiedades antibacterianas, antifúngicas y alelopáticas de extractos de hojas de Myrcia hatschbachii. El extracto crudo y las fracciones se obtuvieron mediante Soxhlet. La actividad antimicrobiana se determinó mediante la concentración mínima inhibitoria (CMI) utilizando el método de microdilución en caldo. La fracción de acetato de etilo mostró actividad contra Candida albicans (CMI: 62,5 $\mu \mathrm{g} / \mathrm{mL}$ ), Staphylococcus aureus (CMI: $500 \mu \mathrm{g} / \mathrm{mL}$ ) y Pseudomonas aeruginosa (CMI: $1000 \mu \mathrm{g} / \mathrm{mL}$ ). La actividad alelopática evaluó la influencia del extracto crudo y fracciones en la germinación y crecimiento de Lactuca sativa. El extracto crudo y la fracción de cloroformo inhibieron el crecimiento de radícula, mientras que la fracción de hexano inhibió el crecimiento de hipocótilo y radícula de semillas de lechuga en todas las concentraciones $(100-1000 \mu \mathrm{g} / \mathrm{mL})$. El potencial biológico de la especie motiva futuros estudios de nuevos agentes antimicrobianos y bioherbicidas.

Palabras clave: Alelopatía; Antifúngico; Candida albicans; Hipocótilo; Myrtaceae; Radícula.

\section{Introduction}

Plants have been seen as alternatives in the search for potential antimicrobials and natural herbicides. Allelopathy studies the ability of a plant to influence the growth and development of biological and agricultural systems, including positive and negative effects on the germination and development of other plants, through the release of secondary metabolites, especially phenolic compounds, terpenes and alkaloids, which constitute a primary source of potential allelochemicals (Macías et al., 2000; Reigosa et al., 2013). The search for plants with metabolites of allelopathic action has been explored for the production of bioherbicides as a perspective for sustainable agriculture, since they reduce the environmental impact caused by agrochemicals, besides presenting a lower cost compared to the traditional herbicide (Santiago et al., 2017).

In addition, plant species are potential sources of new drugs for infectious diseases (Sa et al., 2017). Infectious diseases are of great interest in the scientific community, as some microorganisms cause severe morbidity and can be lethal. Studies on the antimicrobial properties of natural products have increased in the last decade, as microorganisms have become resistant to various drugs used routinely and this motivates the search in plants for alternative therapies with new agents, and moreover, many species are used as antiseptic drugs in folk medicine. Among them, the Myrtaceae family stands out, which was extensively researched for its antimicrobial effects (Özçelik et al., 2011; Santana et al., 2018; Santos et al., 2018).

Myrcia genus contains more than 300 species distributed in Brazil (Franco et al., 2015). Indigenous tribes and traditional Brazilian communities have been using some of these species as astringents, diuretics, to stop bleeding, against diabetes, diarrhoea, hypertension, and mouth ulcers (Cerqueira et al., 2007). Myrcia hatschbachii D. Legrand is a native and endemic tree from the Southern states of Brazil (BFG, 2018). Considering the biological potential of the genus, the aim of this work was to evaluate the antibacterial, antifungal and allelopathic activities in the extracts of species, since these effects were previously demonstrated in its essential oil (Gatto et al., 2020).

\section{Methodology}

\subsection{Plant material}

Leaves of M. hatschbachii were collected at the Federal University of Parana, Curitiba, Brazil (2526'52'S and $\left.49^{\circ} 14^{\prime} 25^{\prime \prime} \mathrm{W}\right)$. Species identification was performed by comparison of the collection voucher with the specimen held at Municipal Botanical Museum of Curitiba (MBM), under registry number 72379. Access to the plant material was approved and licensed by the Ministry of the Environment and registered under number 02001.001165/2013-47. The leaves were dried at 
room temperature and crushed in a knife and hammer mill.

\subsection{Thermal analysis}

Dried leaves $(10 \mathrm{mg})$ were heated at a constant rate of $10^{\circ} \mathrm{C} / \mathrm{min}$, being obtained in the temperature range between 20 and $550^{\circ} \mathrm{C}$, under argon flow $(50 \mathrm{~mL} / \mathrm{min})$, in an open alumina calorimetric cell. The STA 6000 instrument (PERKIN ELMER, Whaltam, MA, United States) was calibrated using Indium (In; PF: $156.6^{\circ} \mathrm{C} ; \Delta \mathrm{H}$ fusion: $28.54 \mathrm{~J} / \mathrm{g}$ ) as standard. The study was carried out using the Origin 9.0 program.

\subsection{Crude extract and fractions preparation}

Dried and crushed leaves (985 g) were extracted with ethanol by using the modified Soxhlet apparatus (Carvalho et al., 2009). This system underwent heating and was left to reflux for 40 hours. The crude extract (EBF) obtained a yield of $12.8 \%$. From EBF concentrated in a rotary evaporator, the fractions were obtained by the liquid-liquid partition system using the Soxhlet apparatus and solvents of increasing polarity: hexane, chloroform, and ethyl acetate. The resulting fractions were named hexane fraction (FFH), chloroform fraction (FFC), and ethyl acetate fraction (FFA).

\subsection{Antimicrobial activity}

The broth microdilution method was performed according to CLSI, standardized and validated by Veiga et al. (2019). Crude extract and fractions were tested against strains of Staphylococcus aureus ATCC 6538, Pseudomonas aeruginosa ATCC 9027, Escherichia coli ATCC 8738, and Candida albicans ATCC 10231. EBF, FFC, and FFA were solubilized in 10\% methanol and FFH in $20 \%$ methanol in sterile water. The microorganisms were inoculated in TSA (bacteria) and sabouraud (yeast) agar and incubated at $33-35^{\circ} \mathrm{C} / 18-22$ hours. After incubation, part of the isolated colonies was transferred to tubes containing saline solution $(0.9 \%)$ and the turbidity was adjusted to 0.5 on the McFarland Scale. In microplates, $100 \mu \mathrm{L}$ of broth (mueller hinton for bacteria and sabouraud dextrose for yeast) were added in all the orifices. Then, $100 \mu \mathrm{L}$ of the samples were added in triplicate in the first line and from this, serial dilutions were performed, maintaining the final volume in all orifices of $100 \mu \mathrm{L}$ and obtaining concentrations of $7.8-1000 \mu \mathrm{g} / \mathrm{mL}$. Positive controls $(100 \mu \mathrm{L}$ of broth $+100 \mu \mathrm{L}$ of $250 \mu \mathrm{g} / \mathrm{mL}$ chloramphenicol for bacteria or $500 \mu \mathrm{g} / \mathrm{mL}$ ketoconazole for yeast), negative control (100 $\mu \mathrm{L}$ of broth $+100 \mu \mathrm{L}$ of diluting solution), and blank (100 $\mu \mathrm{L}$ broth $+100 \mu \mathrm{L}$ of tested sample) were also prepared and $100 \mu \mathrm{L}$ were discarded so that all the orifices in the microplate had the same volume. Suspension of microorganisms $(10 \mu \mathrm{L})$ for the samples and controls, and saline $(10 \mu \mathrm{L})$ for the blank were added to the plates, which were incubated at $33-35^{\circ} \mathrm{C} / 20-22$ hours. After incubation, $20 \mu \mathrm{L}$ of $0.125 \% 2,3,5$ triphenyltetrazolium chloride developer solution was added and the plates were reincubated for 2 hours at 33$35^{\circ} \mathrm{C}$. The results were interpreted by visual readings, observing the development of pink color for bacteria and the deposit of cells (white to pink button) for yeast. The minimum inhibitory concentration (MIC) is the last concentration that did not develop color and is interpreted as good activity (up to $100 \mu \mathrm{g} / \mathrm{mL}$ ), moderate $(100-500 \mu \mathrm{g} / \mathrm{mL}$ ), weak $(500-1000 \mu \mathrm{g} / \mathrm{mL}$ ), or inactive (> $1000 \mu \mathrm{g} / \mathrm{mL}$ ) (Tanaka et al., 2005; Ayres et al., 2008; Santos et al., 2008).

The concentrations of samples that inhibited microbial growth were evaluated for their bactericidal/fungicidal or bacteriostatic/fungistatic action. For this, the samples were transferred to TSA (bacteria) and sabouraud (yeast) agar and incubated at $33-35^{\circ} \mathrm{C} / 18$ hours. The microbiological growth on the agar evidences the bacteriostatic or fungistatic action and the non-growth evidences the bactericidal or fungicidal action (Santurio et al., 2007).

\subsection{Allelopathic activity}

The method was based on Macías et al. (2000), Chon et al. (2005), and Dias et al. (2005) and evaluated the influence of crude extract and fractions on the germination and growth of Lactuca sativa seeds. Extract and fractions solutions were 
prepared in methanol to obtain concentrations of 100-1000 $\mu \mathrm{g} / \mathrm{mL}$. Distilled water and methanol were used as controls. Gerbox boxes were sanitized with solutions of hypochlorite and $70 \%$ alcohol and two autoclaved Whatman ${ }^{\circledR}$ filter papers were added. In laminar flow, a volume of $6 \mathrm{~mL}$ of sample was added to boxes, as well as $6 \mathrm{~mL}$ of methanol were added to the solvent control boxes. For each test, two boxes were used: one for germination and one for growth. The boxes were left at room temperature for 24 hours. After total evaporation, the filter papers were moistened with $6 \mathrm{ml}$ of distilled water. In this stage, control boxes containing water were also prepared. Gerbox boxes were divided into four quadrants and in each of them, five lettuce seeds (L. sativa variety Grand rapids) were deposited, totaling 20 seeds per box. After accommodating the seeds, the boxes were incubated in a BOD at $20 \pm 5^{\circ} \mathrm{C}$. In the germination evaluation, daily readings were taken for 7 days, with the germinated seeds removed. In addition, the germination speed index (GSI) was calculated according to Maguire (1962). The growth verification was performed on the seventh and last day of the test, through the reading in millimeters (mm) of the hypocotyl and radicle. The verification of the differences of the statistically significant means were made by the Scott-Knott test $(\mathrm{p}<0.05)$ using the Sisvar software version 5.6.

\section{Results and Discussion}

Thermal analysis evaluated the physical property of a substance and/or its reaction products. This substance is subjected to controlled temperature programming and under a specific atmosphere, which variations in mass are observed, using a thermobalance of high sensitivity and reproducibility. The data obtained provide information regarding the composition and thermal stability of the sample (Silva et al., 2007) and can be seen in Table 1. The thermal degradation profile of the leaves of the species shows four mass losses in an argon atmosphere. In step two, the decomposition of secondary metabolites such as flavonoids, tannins, and terpenes was evaluated and it was found that the leaves have good thermal stability up to $124^{\circ} \mathrm{C}$, which guarantees thermal reliability in the hot extraction processes, as in Soxhlet apparatus, which was used to obtain the extract and fractions.

Table 1. Stages of thermal degradation in an argon atmosphere of leaves of Myrcia hatschbachii.

\begin{tabular}{llrcc}
\hline Stage & Temperature & ${ }^{\mathbf{0}} \mathbf{C}$ & Mass (\%) \\
\hline \multirow{2}{*}{1} & Humidity & Initial & 20 & \multirow{2}{*}{6,6} \\
& & Final & 130 & \\
2 & Decomposition of secondary metabolites & Initial & 124 & 46 \\
& Slow decomposition of carbonaceous & Final & 402 & \\
3 & Initial & 405 & \multirow{2}{*}{15,4} \\
& residues and polymers & Final & 550 & \\
4 & Carbonaceous residues & Initial & 550 & 32 \\
\hline
\end{tabular}

Note: \% - Percentage of degraded mass in each stage.

Source: Authors (2021).

Table 2 shows the MIC results of the samples against the tested microorganisms. Previous studies have also shown activity in the extracts of genus and family (Syzygium, Eucalyptus, and Eugenia genus) and were compared to those obtained by $M$. hatschbachii. The species showed a fungistatic effect against $C$. albicans in all samples, with emphasis on EBF and FFA (MIC: $62.5 \mu \mathrm{g} / \mathrm{mL}$ ). Extracts of Myrcia bella and Myrcia fallax were inactive (Santos et al., 2018), while extract and fractions of Myrcia tomentosa were effective against several yeast strains (MIC: 4-256 $\mu \mathrm{g} / \mathrm{mL}$; Sa et al., 2017). In the family, extracts of Syzygium cumini (MIC: $125 \mu \mathrm{g} / \mathrm{mL}$; Pereira et al., 2016), Eucalyptus intertexta (MIC: $62.5 \mu \mathrm{g} / \mathrm{mL}$ ), Eucalyptus largiflorens (MIC: $31.2-125 \mu \mathrm{g} / \mathrm{mL}$; Safaei-Ghomi \& Ahd, 2010), and Eugenia caryophyllus (MIC: $17.41 \mathrm{mg} / \mathrm{mL}$; Thirach et al., 2003) also demonstrated activity. 
Phenolic compounds and hydrolysable tannins may justify the antimicrobial effect in the Myrcia genus. The antiinfective actions of tannins are associated with stimulation of phagocytic cells and host-mediated tumour activity (SANTOS et al., 2018). While phenolic compounds induce damage to the antifungal membrane and increase cell permeability. These characteristics are related to its antimicrobial activity (SA et al., 2017) and corroborate the results obtained for $M$. hatschbachii. FGA showed high antifungal activity (MIC: $62.5 \mu \mathrm{g} / \mathrm{mL}$ ) and in previous studies, this same sample showed $75 \%$ of phenolics in its composition, antioxidant potential, and the identification of gallic and ellagic acids, which are phenolics and hydrolysable tannin precursors. In addition, phytochemical screening performed by thin layer chromatography on EBF and FFA showed the presence of tannins, flavonoids and coumarins (GATTO et al., 2021).

Hydrolysable tannins (gallotannins and ellagitannins) were also found in M. guianensis, M. bella, and M. fallax (Santos et al., 2018). Acetylated ellagic acid rhamnosides were identified in Myrcia palustris (Wubshet et al., 2015). Tannins also have anti-infectious actions, such as stimulation of phagocytic cells and host-mediated tumor activity (Santos et al., 2018) and some of them showed antifungal properties, such as corilagin, pelargoniin B, and phyllantusiin C (MIC: $500 \mu \mathrm{g} / \mathrm{mL}$; Latté \& Kolodziej, 2000).

Table 2. Antimicrobial activity expressed in MIC of crude extract and fractions of Myrcia hatschbachii.

\begin{tabular}{|c|c|c|c|c|}
\hline \multirow[b]{2}{*}{ Samples } & \multicolumn{4}{|c|}{ Microorganisms } \\
\hline & $\begin{array}{c}\text { C. albicans } \\
\text { MIC }(\mu \mathrm{g} / \mathrm{mL})\end{array}$ & $\begin{array}{c}\text { S. aureus } \\
\text { MIC }(\mu \mathrm{g} / \mathrm{mL})\end{array}$ & $\begin{array}{l}\text { P. aeruginosa } \\
\text { MIC }(\mu \mathrm{g} / \mathrm{mL})\end{array}$ & $\begin{array}{c}\text { E. coli } \\
\text { MIC }(\mu \mathrm{g} / \mathrm{mL})\end{array}$ \\
\hline EBF & 62.5 & 500 & $>1000$ & $>1000$ \\
\hline FFH & 500 & 500 & $>1000$ & $>1000$ \\
\hline FFC & 250 & 1000 & $>1000$ & $>1000$ \\
\hline FFA & 62.5 & 500 & 1000 & $>1000$ \\
\hline
\end{tabular}

Note: Minimum inhibitory concentration (MIC); crude extract (EBF); hexane fraction (FFH); chloroform fraction (FFC); ethyl acetate fraction (FFA).

Source: Authors (2021).

The bacteriostatic effect was observed against $S$. aureus at a concentration of $500 \mu \mathrm{g} / \mathrm{mL}$ of EBF and FFA, however at the concentration of $1000 \mu \mathrm{g} / \mathrm{mL}$, the bactericidal effect was seen in both. The other samples tested showed a bacteriostatic effect. In view of the same strain, the M. tomentosa species showed activity for the crude extract and fractions of ethyl acetate (MIC: $1000 \mu \mathrm{g} / \mathrm{mL}$ ) and hexane (MIC: $250 \mu \mathrm{g} / \mathrm{mL}$; Sa et al., 2017), as well as aqueous extract of E. largiflorens (MIC: 7.8 $\mu \mathrm{g} / \mathrm{mL}$; Safaei-Ghomi \& Ahd, 2010).

M. hatschbachii species was inactive for P. aeruginosa, except for FFA, which demonstrated a bacteriostatic effect, with a MIC of $1000 \mu \mathrm{g} / \mathrm{mL}$. Studies from leaves of M. tomentosa showed activity for crude extract and ethyl acetate (MIC: 500 $\mu \mathrm{g} / \mathrm{mL}$ ) and hexane (MIC: $1000 \mu \mathrm{g} / \mathrm{mL}$ ) fractions (Sa et al., 2017), as well as in aqueous extracts of E. intertexta and $E$. largiflorens (MIC: $31.2 \mu \mathrm{g} / \mathrm{mL}$; Safaei-Ghomi \& Ahd, 2010).

In relation to E. coli, the species samples were shown to be inactive, whereas the leaves extracts of M. bella and M. fallax demonstrated activity (300 and $250 \mu \mathrm{g} / \mathrm{mL}$, respectively; Santos et al., 2018), as well such as the chloroform fraction of E. largiflorens (MIC: $125 \mu \mathrm{g} / \mathrm{mL}$; Safaei-Ghomi \& Ahd, 2010). The presence of an external membrane over the peptidoglycan, presence of capsule and porins may be the reason for the low activity of the extracts in gram-negative bacteria, such as $P$. aeruginosa and E. coli. These structural characteristics differ in relation to gram-positive bacteria and can hinder the action of bioactive components (Ayres et al., 2008; Santana et al., 2018).

The crude extract and fractions of $M$. hatschbachii did not influence germination and GSI of L. sativa in the tested concentrations. The seeds are considered germinated with the appearance of the radicle protrusion through the tegument (De Feo et al., 2002). The growth verification was performed by reading the length of the hypocotyl and radicle after seven days of storage in a BOD. Allelochemicals accumulate predominantly in the leaves and are released into the environment via root 
exudates in the soil or by volatile substances in the air. Its effects on plant growth are related to cell division, organic synthesis, hormonal interactions, nutrient absorption, inhibition of protein synthesis, changes in lipid metabolism, stomatal opening, $\mathrm{CO}_{2}$ assimilation and photosynthesis (Franco et al., 2015; Silva et al., 2012).

FFH (group a) inhibited the hypocotyl of L. sativa (Figure 1A) at all concentrations tested when compared statistically to the water and methanol (group b). While EBF, FFH, and FFC (group a) inhibited the radicle (Figure 1B) at all concentrations compared to the same controls (group b).

Figure 1. Influence of crude extract and fractions of Myrcia hatschbachii on the growth of the hypocotyl (A) and radicle (B) of Lactuca sativa
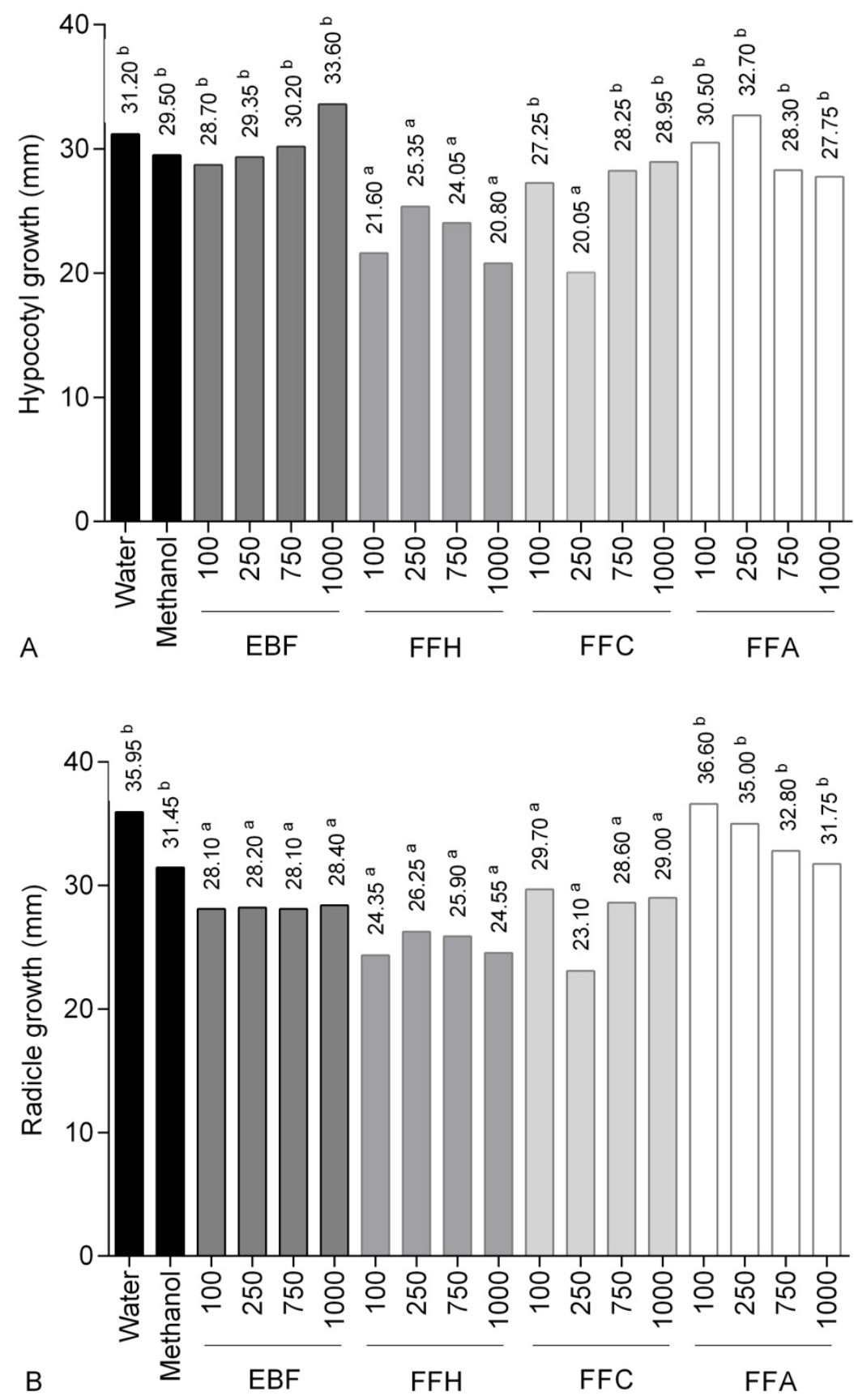

Note: Crude extract (EBF); hexane fraction (FFH); chloroform fraction (FFC); ethyl acetate fraction (FFA). Samples classified in the same group do not differ significantly ( $<0.05$ ), as determined by the Scott Knott test.

Source: Authors (2021). 
Classic studies of allelopathy have progressed over the years, but molecular advances need further investigation to better understand allelopathic action, especially in relation to root development. The inhibition of root development due to allelopathic activity is initially attributed to changes in gene expression (Franco et al., 2015).

Allelopathic activity has also been described for other species of the Myrcia genus and involve studies of inhibition and stimulation of germination and growth of hypocotyl and radicle.

The hydromethanolic extract of leaves of M. guianensis drastically inhibited the development of roots of Sorghum bicolor (sorghum) and altered the expression of SHR and PHB genes and microRNA 166, which can be used as indicators of allelopathic potential in root development (Franco et al., 2015). Another study with the species showed that extracts of ethyl acetate and methanol from leaves inhibited the germination of seeds of Mimosa pudica (malice), whereas the hexane and ethyl acetate fractions showed inhibition of growth of hypocotyl and radicle (Souza Filho et al., 2006).

Extracts of ethyl acetate and acetone from leaves of $M$. tomentosa showed a potent inhibition of coleoptile elongation when tested on Triticum aestivum (wheat). The germination rate of seeds of Lepidium sativum (watercress) and the growth of hypocotyl of L. sativa (lettuce) were also significantly inhibited by dichloromethane, ethyl acetate, acetone and methanol extracts (Imatomi et al., 2013).

The aqueous extracts of leaves of M. multiflora, Myrcia splendens, and M. tomentosa promoted marked delays in seed germination and inhibited the growth of seedlings of Echinochloa crusgalli, Euphorbia heterophylla, and Ipomoea grandifolia, even with more efficient effects than the herbicide oxyfluorfen (Imatomi et al., 2015).

The main biosynthetic pathways that lead to the production of allelochemicals are derived from acetate or chiquimate. Phenolic acids are the compounds most commonly investigated for this purpose, especially p-hydroxybenzoic, vanillic, $p$ coumaric, syringic and ferulic acids (Chon et al., 2005). Most phenolic compounds are released simultaneously and continuously, perhaps acting synergistically. In addition, chemical interactions between plants are almost never limited to a compound, but to mixtures of various substances, often complex, and these mixtures can have synergistic or antagonistic effects, which can be modified by the chemical, physical and biotic properties of the soil (Reigosa et al., 2013).

\section{Conclusion}

Extracts of $M$. hatschbachii showed fungistatic and bacteriostatic activities in all samples and concentrations when tested against $C$. albicans and $S$ aureus, respectively, except for the crude extract and ethyl acetate fraction, which showed a bactericidal effect at $1000 \mu \mathrm{g} / \mathrm{mL}$ against $S$ aureus. The crude extract and the chloroform fraction inhibited the growth of the radicle of $L$. sativa, while the hexane fraction inhibited the growth of the hypocotyl and the radicle of the lettuce seeds at all concentrations (100-1000 $\mu \mathrm{g} / \mathrm{mL})$. The biological potential of the species motivates the in-depth study of new antimicrobial and bioherbicidal agents.

\section{Acknowledgments}

This work was carried out with the support of the Coordination of Improvement of Higher Education Personnel Brazil (CAPES) - Financing Code 001. The authors are grateful to UEPG for the assistance in the thermal analysis.

\section{References}

Ayres, M. C. C., Brandão, M. S., Vieira-Júnior, G. M., Menor, J. C. A. S., Silva, H. B., Soares, M. J. S., \& Chaves, M. H. (2008). Atividade antibacteriana de plantas úteis e constituintes químicos da raiz de Copernicia prunifera. Rev. Bras. Farmacogn, 18(1), 90-97.

BFG - The Brazil Flora Group. (2018). Brazilian Flora 2020: innovation and collaboration to meet Target 1 of the Global Strategy for Plant Conservation (GSPC). Rodriguésia, 69, 1513-1527. 
Carvalho, J. L. S., Cunico, M. M., Dias, J. F. G., Miguel, M. D., \& Miguel, O. G. (2009). Termoestabilidade de processos extrativos de Nasturtium officinale R. Br., Brassicaceae por sistema de Soxhlet modificado. Quim. Nova, 32(4), 1031-1035.

Cerqueira, M. D., Souza-Neta, L. C., Passos, M. G. V. M., Lima, E. O., Roque, N. F., Martins, D., Guedes, M. L. S., \& Cruz, F. G. (2007). Seasonal Variation and Antimicrobial Activity of Myrcia myrtifolia essential oils. J. Braz. Chem. Soc., 18(5), 998-1003.

Chon, S. U., Jang, H. G., Kim, D. K., Kim, Y. M., Boo, H. O., \& Kim, Y. J. (2005). Allelopathic potential in lettuce (Lactuca sativa L.) plants. Sci. Hortic., 106(3), 309-317.

Clinical and Laboratory Standard Institute - CLSI. (2008). Methods for dilution antimicrobial susceptibility tests for bacteria that grow aerobically. M07-A8.

De Feo, V., De Simone, F., \& Senatore, F. (2002). Potential allelochemicals from the essential oil of Ruta graveolens. Phytochemistry, 61(5), 573-578.

Dias, J. F. G., Círio, G. M., Miguel, M. D., \& Miguel, O. G. (2005). Contribution to the allelophatic study of Maytenus ilicifolia Mart. ex Reiss, Celastraceae. Rev. Bras. Farmacogn, 15(3), 220-223.

Franco, D. M., Saldanha, L. L., Silva, E. M., Nogueira, F. T. S., Dokkedal, A. L., Santos, C., \& Almeida, L. F. R. (2015). Effects of leaf extracts of Myrcia guianensis (Aubl.) DC: on growth and gene expression during root development of Sorghum bicolor (L.) Moench. Allelophathy J, 35(2), 237-248.

Gatto, L. J., Fabri, N. T., Souza, A. M., Fonseca, N. S. T., Furusho, A. S., Miguel, O. G., Dias, J. F. G., Zanin, S. M. Z., \& Miguel, M. D. (2020). Chemical composition, phytotoxic potential, biological activities and antioxidant properties of Myrcia hatschbachii D. Legrand essential oil. Braz. J. Pharm. Sci, 56, 1-9.

Gatto, L. J., Oliveira, G. R. B., Rech, K. S., Moura, P. F., Gribner, C., Merino, F. J., Ávila, S., Dias, J. F. G., Miguel, O. G., \& Miguel, M. D. (2021). Inhibition of $\alpha$-glucosidase, pancreatic lipase, and antioxidant property of Myrcia hatschbachii D. Legrand containing gallic and ellagic acids. Bol. Latinoam. Caribe Plant. Med. Aromat., 20 (3), 226-243.

Imatomi, M., Novaes, P., Matos, A. P., Gualtieri, S. C. J., Molinillo, J. M. G., Lacret, R., Varela, R. M., \& Macías, F. A. (2013). Phytotoxic effect of bioactive compounds isolated from Myrcia tomentosa (Myrtaceae) leaves. Biochem. Syst. Ecol., 46, 29-35.

Imatomi, M., Novaes, P., Miranda, M. A. F. M., \& Gualtieri, S. C. J. (2015). Phytotoxic effects of aqueous leaf extracts of four Myrtaceae species on three weeds. Acta Sci., 37(2), 241-248.

Latté, K. P. \& Kolodziej, H. (2000). Antifungal effects of hydrolysable tannins andrelated compounds on dermatophytes, mould fungi and yeasts. Z. Naturforsch., 55, 467-472.

Macías, F. A., Castellano, D., \& Molinillo, J. M. (2000). Search for a standard phytotoxic bioassay for allelochemicals. Selection of standard target species. J. Agric. Food Chemistry, 48(6), 2512-2521.

Maguire, J. D. (1962). Speed of germination-aid in selection and evaluation for seedling emergence and vigor. Crop sci., 2(2), $176-177$.

Özçelik, B., Kartal, M., \& Orhan, I. (2011). Cytotoxicity, antiviral and antimicrobial activities of alkaloids, flavonoids, and phenolic acids. Pharm. Biol., 49(4), 396-402.

Pereira, J. V., Freires, I. A., Castilho, A. R., Cunha, M. G., Alves, H. S., \& Rosalen, P. L. (2016). Antifungal potential of Sideroxylon obtusifolium and Syzygium cumini and their mode of action against Candida albicans. Pharm. Biol., 54(10), 2312-2319.

Reigosa, M., Gomes, A. S., Ferreira, A. G., \& Borghetti, F. (2013). Allelopathic research in Brazil. Acta Bot. Bras., 27(4), 629-646.

Sa, F. A. S., Paula, J. A. M., Santos, P. A., Oliveira, L. A. R., Oliveira, G. A. R., Lião, L. M., Paula, J. R., \& Silva, M. R. R. (2017). Phytochemical Analysis and Antimicrobial Activity of Myrcia tomentosa (Aubl.) DC. Leaves. Molecules, 22(1100), 1-10.

Safaei-Ghomi, J. \& Ahd, A. A. (2010). Antimicrobial and antifungal properties of the essential oil and methanol extracts of Eucalyptus largiflorens and Eucalyptus intertexta. Pharmacogn. Mag., 6(23), 172-176.

Santana, C. B., Souza, J. G. L., Coracini, M. D. A., Walerius, A. H., Soares, V. D., Costa, W. F., \& Pinto, F. G. S. (2018). Chemical composition of essential oil from Myrcia oblongata DC and potencial antimicrobial, antioxidant and acaricidal activity against Dermanyssus gallinae (DEGEER, 1778). Biosci. J., 34(4), 996-1009.

Santiago, J. A., Cardoso, M. G., Cruz, F. A., Palmieri, M. J., Souza, R. V., Soares, L. I., Campos, J. M. S., \& Andrade-Vieira, L. F. (2017). Cytogenotoxic effect of essential oil from Backhousia citriodora L. (Myrtaceae) on meristematic cells of Lactuca sativa L. South Afr. J. Bot., 112, $515-520$.

Santos, A. O., Nakamura, T. U., Dias Filho, B. P., Veiga Junior, V. F., Pinto, A. C., \& Nakamura, C. V. (2008). Antimicrobial activity of Brazilian copaiba oils obtained from different species of the Copaifera genus. Mem. Inst. Oswaldo Cruz, 103(3), $277-281$.

Santos, C., Galaverna, R. S., Angolini, C. F. F., Nunes, V. V. A., Almeida, L. F. R., Ruiz, A. L. T. G., Carvalho, J. E., Duarte, R. M. T., Duarte, M. C. T., \& Eberlin, M. N. (2018). Antioxidative, Antiproliferative and Antimicrobial Activities of Phenolic Compounds from Three Myrcia Species. Molecules, 23, 1-12.

Santurio, J. M., Santurio, D. F., Pozzatti, P., Moraes, C., Franchin, P. R., \& Alves, S. H. (2007). Atividade antimicrobiana dos óleos essenciais de orégano, tomilho e canela frente a sorovares de Salmonella enterica de origem avícola. Cienc. Rural, 37, 803-808.

Silva, E. C., Paola, M. V. R. V., \& Matos, J. R. (2007). Análise térmica aplicada à cosmetologia. Braz. J. Pharm. Sci, 43(3), 347-356.

Silva, P. S. S. (2012). Atuação dos aleloquímicos no organismo vegetal e formas de utilização da alelopatia na agronomia. Biotemas, 25(3), 65-74.

Souza Filho, A. P. S., Santos, R. A., Santos, L. S., Guilhon, G. M. P., Santos, A. S., Arruda, M. S. P., Muller, A. H., \& Arruda, A. C. (2006). Allelophatic Potential of Myrcia guianensis. Planta Daninha, 24(4), 649-656. 
Research, Society and Development, v. 10, n. 8, e21410817160, 2021

(CC BY 4.0) | ISSN 2525-3409 | DOI: http://dx.doi.org/10.33448/rsd-v10i8.17160

Tanaka, J. C. A., Silva, C. C., Dias Filho, B. P., Nakamura, C. V., Carvalho, J. E., \& Folgio, M. A. (2015). Constituintes químicos de Luehea divaricata Mart. (Tiliaceae). Quím. Nova, 28(5), 834-837.

Thirach, S., Tragoolpua, K., \& Punjaisee, S. (2003). Antifungal Activity of Some Medicinal Plant Extracts Against Candida albicans and Cryptococcus neoformans. Acta Hortic., 597, 217-221.

Veiga, A., Toledo, M. G. T., Rossa, L. S., Mengarda, M., Stofella, N. C. F., Oliveira, L. J., Gonçalves, A. G., \& Murakami, F. S. (2019). Colorimetric microdilution assay: Validation of a standard method for determination of MIC, IC $50 \%$, and IC $90 \%$ of antimicrobial compounds. J. Microbiol. Methods, 162 , $50-61$.

Wubshet, S. G., Moresco, H. H., Tahtah, H., Brighente, I. M. C., \& Staerk, D. (2015). High-resolution bioactivity profiling combined with HPLC-HRMSSPE-NMR: a-Glucosidase inhibitors and acetylated ellagic acid rhamnosides from Myrcia palustris DC. (Myrtaceae). Phytochemistry,116, 246 